\title{
Perancangan Sistem Informasi Jurnal Mengajar Dosen Berbasis Web Pada Fakultas Keguruan Dan Ilmu Pendidikan Universitas Pendidikan Muhammadiyah Sorong
}

\author{
Firman, Novita Wulandari, Acep Irawan \\ Universitas Pendidikan Muhammadiyah Sorong \\ firmantjadiduliman@gmail.com, accepirawan@gmail.com
}

\begin{abstract}
Abstrak: The lecturer teaching journal is a device that must be provided by the lecturer after teaching. From the lecturer's teaching jural, it can be known data such as lecture material, courses, meetings, days, times, dates and even the number of students either present or permission and absenteeism. With the development of technology makes people think to be able to work more efficiently. One of them is making a conventional system into a computerized system. For this reason, in the design of a teaching journal information system for lecturers using the R\&D (research and development) method and the waterfall model, by utilizing web facilities connected to the internet, the aim is to fill lecturer teaching journals efficiently.In this study a web-based information system was designed using DreamWeaver CS6 and XAMPP 3.2.2. Journal information system testing for teaching lecturers uses blackbox, small scale and large scale testing. With this system, it can make it easier to fill teaching journals of lecturers at the PTI Study Program, Faculty of Teacher Training and Education, Unimuda Sorong From the results of research that has been carried out, the writer implements the results of the research into the Information System Design of Lecturer Journal in the Study Program at the PTI Faculty of Teacher Training and Education, Unimuda Sorong.

Keywords: DreamWeaverCs6, Journal, XAMPP, Information Systems, Web
\end{abstract}

\section{Pendahuluan}

Seiring dengan perkembangan zaman yang semakin maju, tentunya akan diiringi pula dengan kemajuan teknologi. Dimana teknologi sejatinya memberikan begitu banyak manfaat bagi manusia dalam berbagai bidang kehidupan, seperti dalam bidang Pendidikan Teknologi adalah cara melakukan sesuatu untuk memenuhi kebutuhan manusia (Permendikbud, 2016). Definisi ini selaras dengan UU ITE nomor 11 tahun 2008, mengenai informasi dan transaksi elektronik. Dan lebih spesifik lagi dalam UU ITE Nomor 11 tahun 2008 dalam BAB V III menjelaskan mengenai standar etika atau perbuatan dalam implementasi TIK.

Teknologi Informasi dalam menunjang sistem informasi membawa pengaruh terhadap hampir semua aspek dalam pengelolaan data pada suatu perguruan tinggi. Keberhasilan sistem informasi pada suatu perguruan tinggi tergantung bagaimana sistem itu dijalankan bagi para pemakainya dan pemanfaatan teknologi yang digunakan. Peran sistem informasi saat ini sangat membantu dalam pengolahan data yang akan di jadikan suatu informasi demi mencapai suatu tujuan seperti di sebuah organisasi atau lembaga-lembaga.

Pemanfaatan teknologi informasi untuk menunjang pengolahan data telah dipraktikkan oleh salah satu perguruan tinggi di Papua Barat yaitu Universitas Pendidikan Muhammadiyah (UNIMUDA) Sorong. UNIMUDA Sorong merupakan salah satu perguruan tinggi yang ada di Papua Barat tepatnya di jalan KH. Ahmad Dahlan No. 1 Kabupaten Sorong Aimas Distrik Sorong Kecamatan Mariyat Pantai yang sudah menyandang predikat Akreditasi B sehingga menjadi kampus terbaik di wilayah Papua, Papua Barat, Maluku, dan 
Maluku Utara hal ini dapat di buktikan dengan SK yang di terbitkan oleh Menristekdikti No. 547/KPT/I/2018. Pada mulanya UNIMUDA Sorong berdiri sejak tahun 2003 dengan terbitan SK PP Muhammadiyah Nomor 78/KEP/l.o/D/2003 tanggal 23 September 2003 tentang pengangkatan ketua STKIP Muhamadiyah Sorong pada saat itu Drs. Rustamadji serta terbitan SK MENDIKNAS RI Nomor 12/D/O/2004 tentang pemberian ijin penyelenggaraan program studi pada STKIP Muhammadiyah Sorong. (Sorong, 2019). Sampai saat ini UNIMUDA Sorong memiliki tiga fakultas diantaranya fakultas keguruan dan ilmu pendidikan (FKIP) dengan sepuluh program studinya, fakultas ilmu sosial dan humaniora dengan dua program studinya serta fakultas sains dan teknologi dengan enam program studinya.

Sejauh ini UNIMUDA Sorong dalam mengelola data dan informasi telah memanfaatkan teknologi informasi untuk keperluan pengolahan data yang nantinya akan dijadikan suatu informasi ataupun dijadikan suatu pengambilan keputusan bersama seperti sistem perpustakaan yang sudah berjalan pada perpustakaan UNIMUDA Sorong dan Website UNIMUDA Sorong. Namum di sisi lain dalam pengelolaan data yang berkaitan dengan UNIMUDA Sorong sebagian masih menggunakan cara manual tidak terkecuali pengisian jurnal mengajar dosen pada Program Studi Pendidikan Teknologi Informasi (PTI). Pengisian jurnal mengajar mengharuskan dosen mengisi dengan cara manual atau konvensional pengisian jurnal mengajar yang dilakukan secara manual ini pun memiliki resiko seperti mudah rusak baik tersobek, terkena air dan resiko hilang (human error). Menanggapi permasalahan yang telah dipaparkan, solusi yang dapat penulis tawarkan ialah perlu dibangunya sebuah sistem jurnal mengajar dosen berbasis web untuk dapat mengatasi permasalahan tersebut.

Diharapkan dengan dibangunya sistem informasi jurnal mengajar dosen berbasis web pada Prodi PTI Fakultas Keguruan Dan Ilmu Pendidikan UNIMUDA Sorong diharapkan akan membantu dosen dalam pengisian jurnal mengajar menjadi lebih mudah baik dalam pengisian maupun dalam penyimpanannya. Berdasarkan uraian diatas, maka peneliti tertarik untuk mengambil permasalahan yang berjudul "Perancangan Sistem Informasi Jurnal Mengajar Dosen Berbasis Web Pada Prodi PTI Fakultas Keguruan dan Ilmu Pendidikan UNIMUDA Sorong".

\section{Metode Penelitian}

a. Jenis penelitian pada perancangan sistem informasi jurnal mengajar dosen berbasis Web pada Prodi PTI Fakultas Keguruan dan Ilmu Pendidikn UNUMUDA Sorong ialah menggunakan jenis Penelitian $R \& D$ (research and Developmen) merupakan penelitian pengembangan yang mempunyai langkah-langkah untuk mengembangkan atau menciptakan sbuah sistem atau produk yang nantinya mempermudah dalam pekerjaan orang.

b. Tempat dan Waktu

Tempat penelitian perancangan sistem informasi mengajar dosen berbasis Web bertempat di Program Studi Pendidikan Teknologi Informasi UNIMUDA Sorong. 03 Mei sampai dengan 26 Oktober 2019.

c. Teknik Pengumpulan Data

Teknik pengumpulan data yang penulis lakukan dengan cara wawancara dan observasi, Wawancara merupakan percakapan dengan maksud mendapatkan informasi yang di butuhkan. Percakapan dilakukan antara peneliti yang mengajukan pertanyaan dengan Sekretaris Prodi PTI UNIMUDA Sorong yaitu Muhammad Ihsan. 
M.Pd. dan yang diwawancarai memberikan jawaban atas pertanyaan itu. Proses wawancara ini dilakukan di Ruang Prodi PTI UNIMUDA Sorong. Sedangkan Tujuan dari observasi adalah dengan mendeskripsikan seting yang sesuia dengan bentuk dokumen asli dari jurnal mengajar dosen. Pada penelitian ini, peneliti mendapatkan data dengan mengamati objek yang akan diteliti secara langsung di tempat penelitian yaitu Prodi PTI UNIMUDA Sorong.

\section{Hasil Pembahasan}

Penelitian ini merancang sebuah sistem informasi Jurnal mengajar dosen berbasis Web pada Prodi PTI Fakultas keguruan dan Ilmu pendidikan UNIMUDA Sorong. Menggunakan Adobe Dreamweaver CS6, sistem infomasi jurnal mengajar ini dibuat untuk mempermudah dosen dalam mengisi jurnal. Adapun penelitian menghasilkan sebuah sistem inforasi pengisian jurnal mengajar dosen, sistem ini pun telah melewati uji blackbox serta telah di uji cobakan kepada responden sebagai berikut :

\section{a. Tamplan Sistem Informasi Mengajar Dosen}

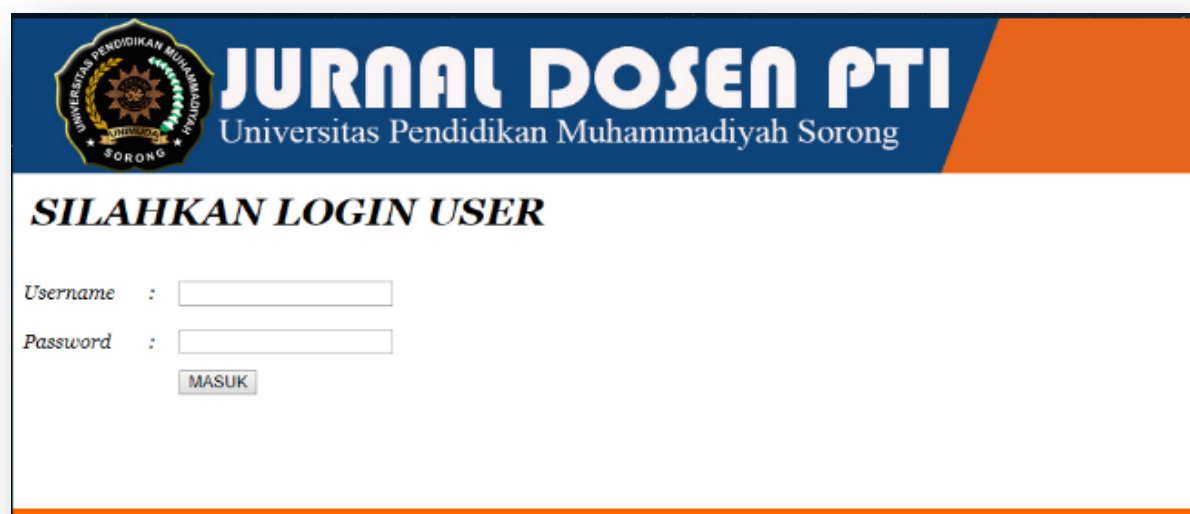


Gambar 3 Header

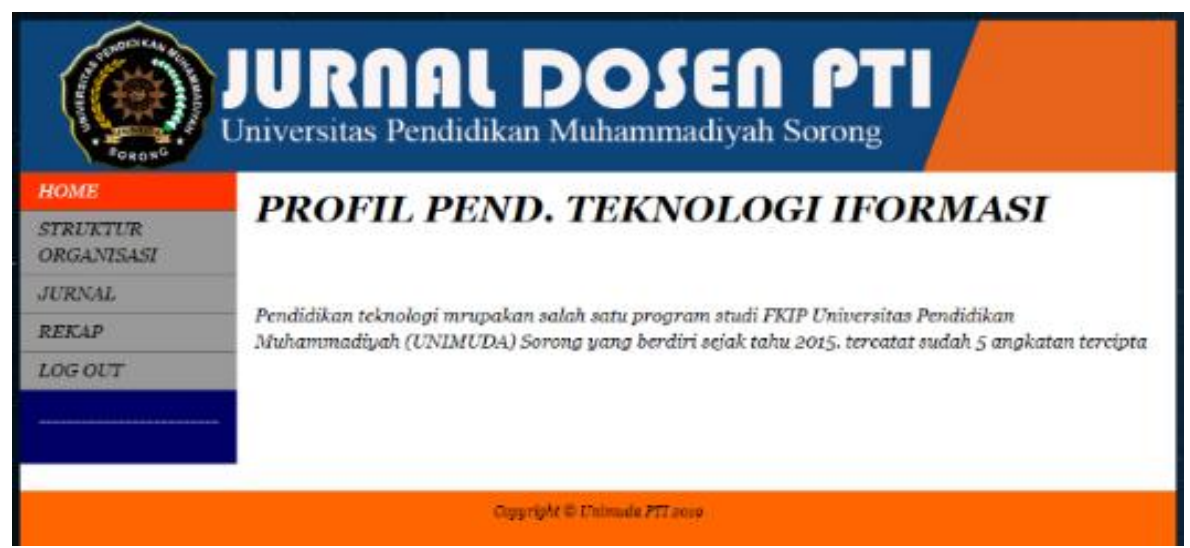

Gambar 4 Home admin

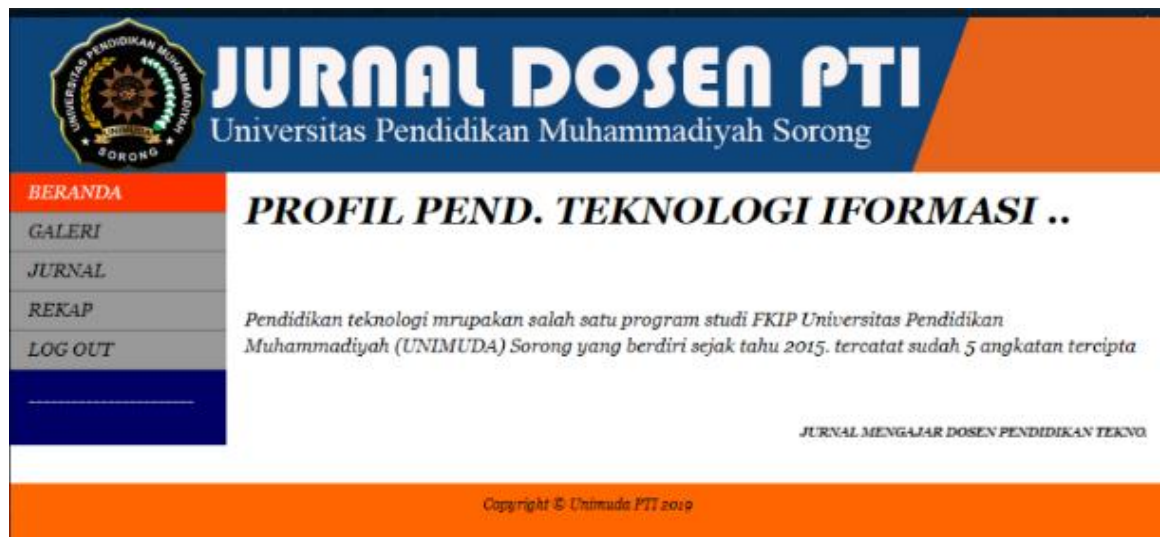

Gambar 5 home user 


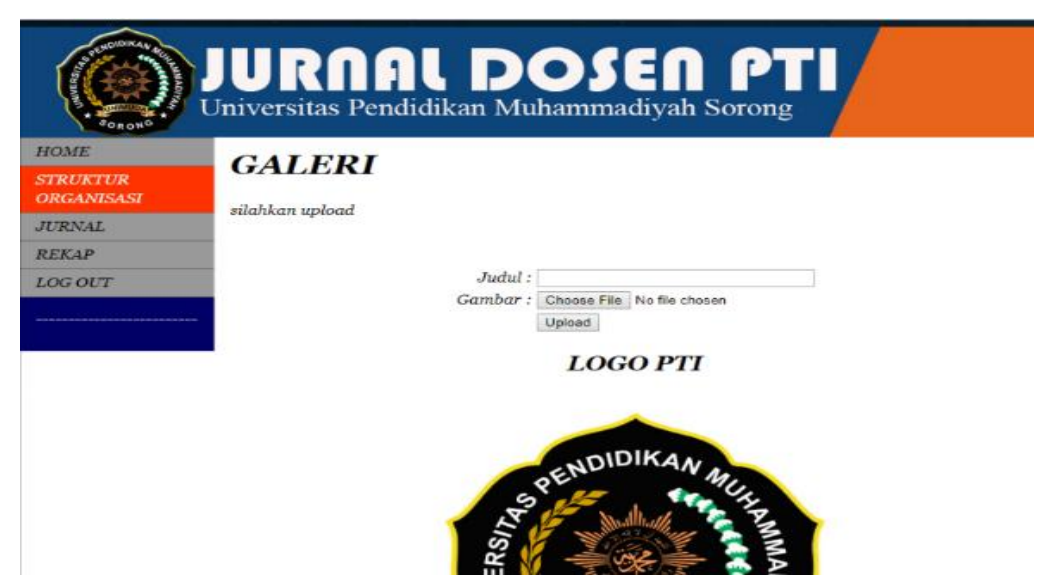

Gambar 6 struktur organisasi admin

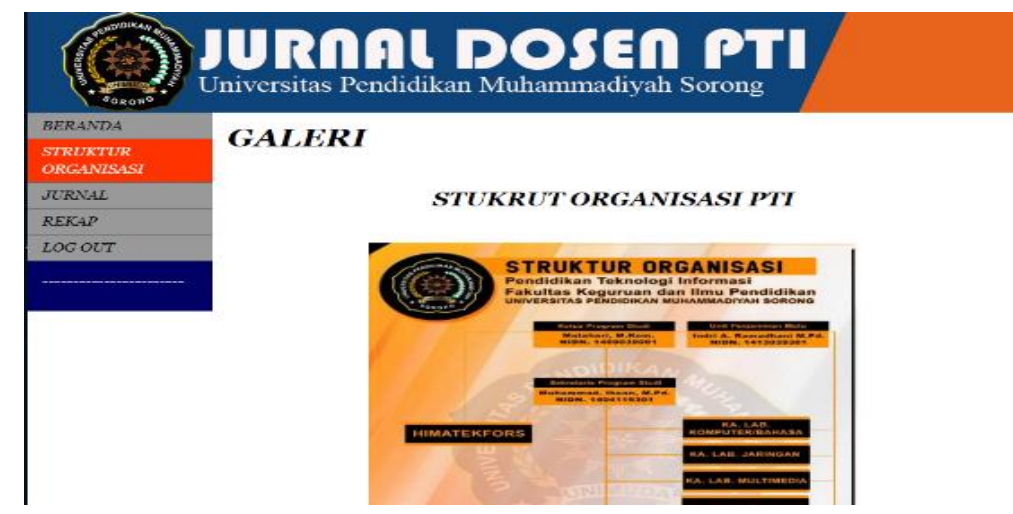

Gambar 7 struktur organisasi user

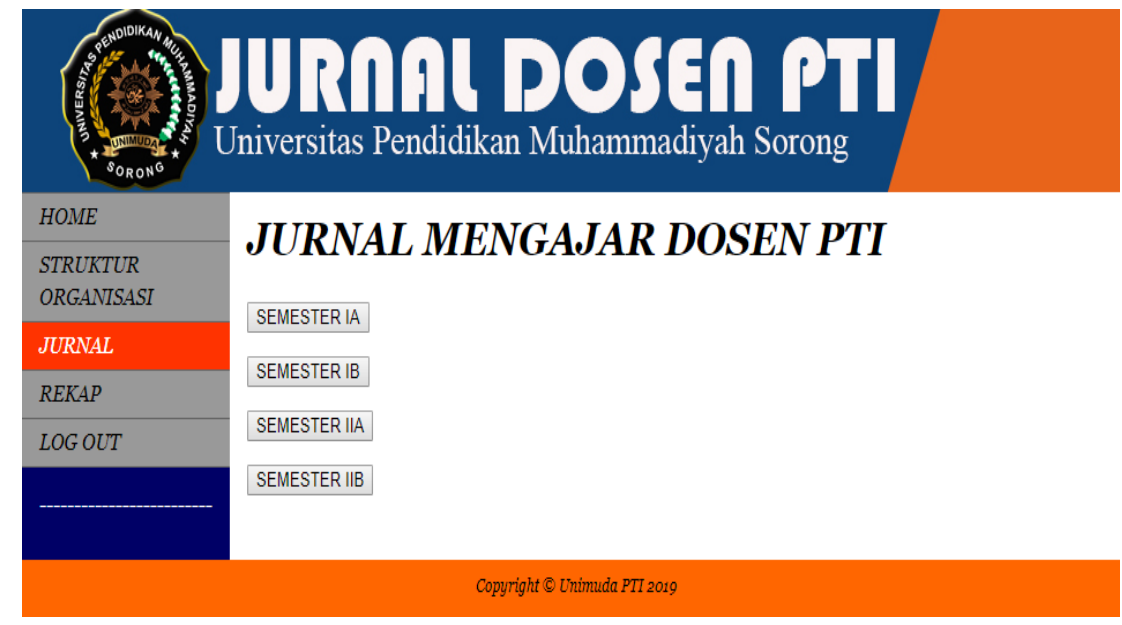

Gambar 8 halaman jurnal admin 


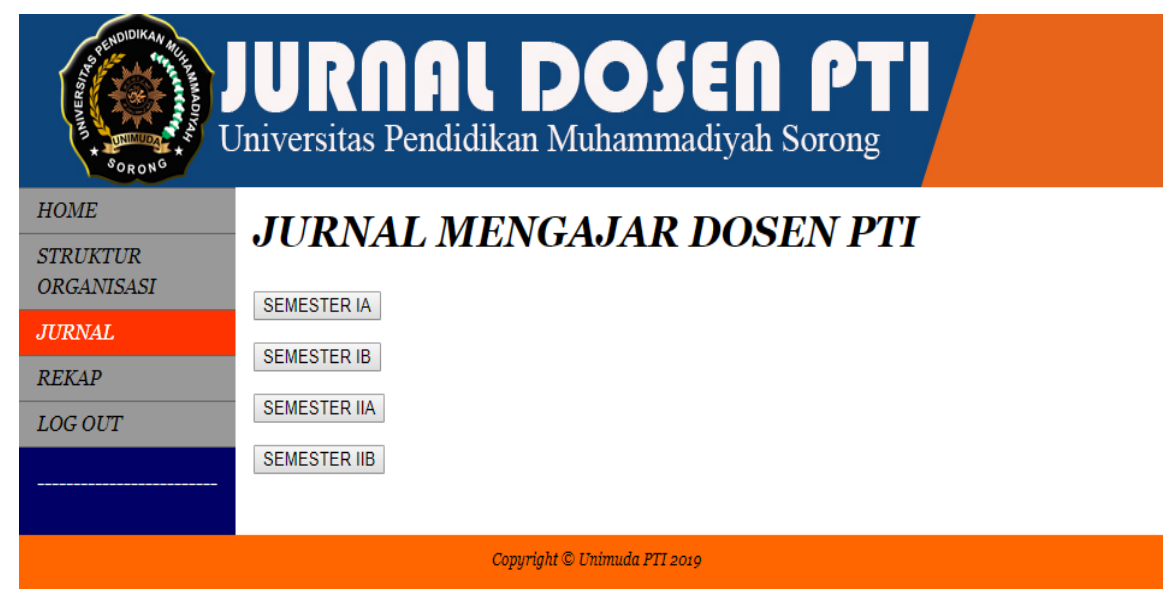

Gambar 9 Halaman jurnal user

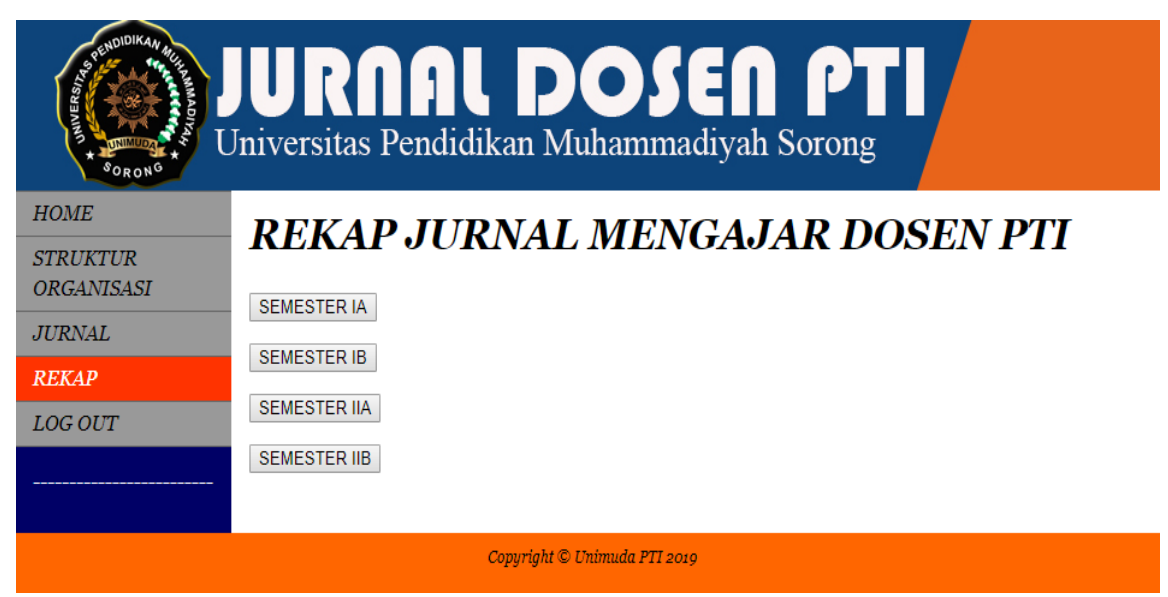

Gambar 10 Halaman rekap admin

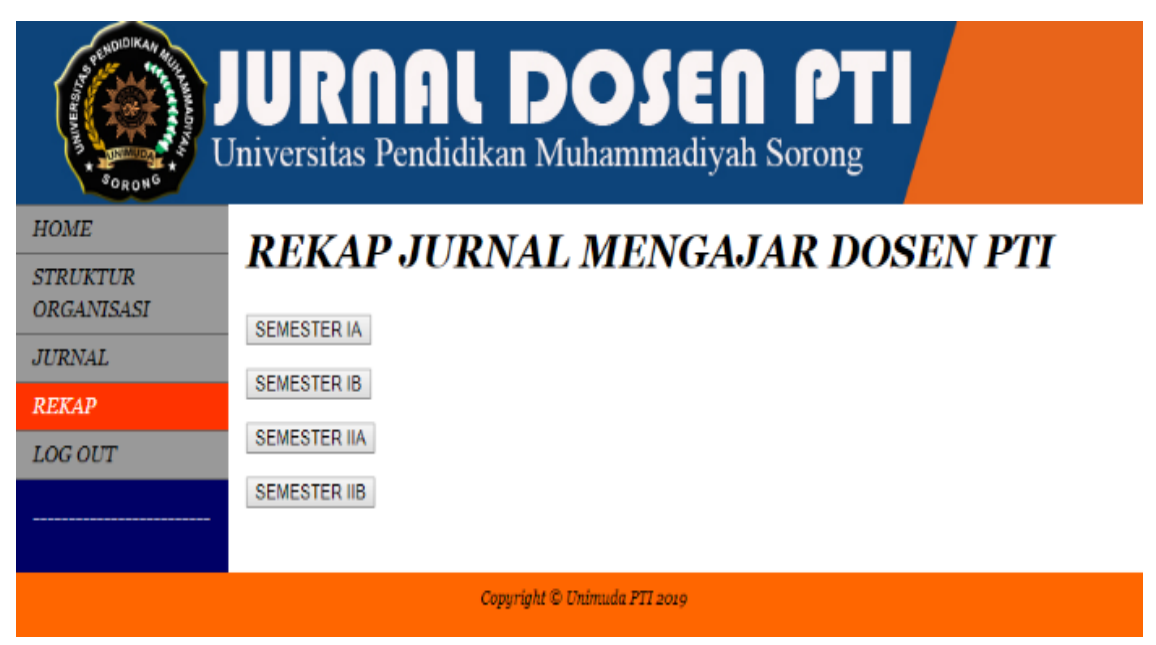

Gambar 11 halaman rekap user 


\section{b. Hasil uji coba Blackbox}

Pengujian blackbox merupakan pengujian secara fungsional tujuannya untuk mengetahui sistem berjalan sesuai keingan dan sesuai perintah, pengujian dilakukan dengan cara memasukan perintah (input) dan mengetahui hasil keluaran (output), pengujian blackbox dilakukan dengan dua level yaitu level admin dan level user. Pengujian blackbox dilakukan oleh dosen ahli yaitu Indri Anugrah R, M. Pd. Pengujian ini dilakukan dengan berbagi situasi dan dilakukan berulang-ulang. Adapun conoth hasil dari pengujian blackbox sebagai berikut :

Tabel 1 Uji Blacbox login admin

\begin{tabular}{|c|c|c|c|}
\hline No & Skenario Pengujian & Hasil yang diharapkan & Kesimpulan \\
\hline 1 & $\begin{array}{l}\text { Mengosongkan username dan } \\
\text { password lalu tekan login } \\
\text { Test } \\
\text { JURnAL DOsen PTI }\end{array}$ & $\begin{array}{l}\text { tidak akan berpindah } \\
\text { halaman, akan tetap pada } \\
\text { halaman login } \\
\text { hasil pengujian } \\
\text { JURngl Dosen PTI } \\
\text { (O) }\end{array}$ & Valid \\
\hline 2 & $\begin{array}{l}\text { Hanya mengisi username } \\
\text { dengan "admin" dan } \\
\text { mengosongkan kolom } \\
\text { password. Lalu tekan login } \\
\text { Test }\end{array}$ & $\begin{array}{l}\text { tidak akan berpindah } \\
\text { halaman, akan tetap pada } \\
\text { halaman login } \\
\text { IURngt posen PTI } \\
\text { Hasilpengujian }\end{array}$ & Valid \\
\hline 3 & $\begin{array}{l}\text { Mengosongkan username dan } \\
\text { hanya mengisi password } \\
\text { dengnan "adminpti". Lalu tekan } \\
\text { login } \\
\text { (2) JURngl DOSEn PTI }\end{array}$ & $\begin{array}{l}\text { tidak akan berpindah } \\
\text { halaman, akan tetap pada } \\
\text { halaman login } \\
\text { Hasil pengujian }\end{array}$ & Valid \\
\hline
\end{tabular}




\begin{tabular}{|c|c|c|c|}
\hline 4 & $\begin{array}{l}\text { Mengisi usernmae dengan } \\
\text { "admin" dan password dengan } \\
\text { "adminpti" lalu tekan login } \\
\text { Test } \\
\text { (2) JURnAL POSEn PTI }\end{array}$ & 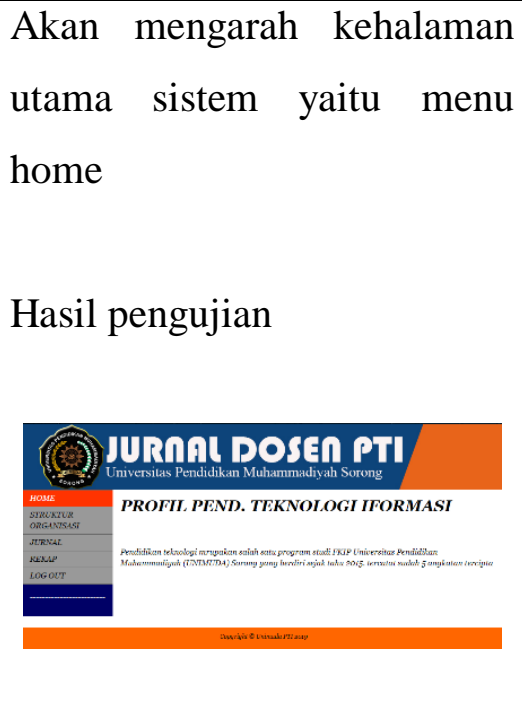 & Valid \\
\hline
\end{tabular}

\section{c. Hasil uji Coba Responden}

Uji coba responden dimaksud untuk mengetahui apakah sistem yang dirancang sudah dapat di pakai secara masal, ujicoba ini dibagi menjadi 2 skala yaitu uji comba kelompok kecil dan uji coba kelompok besar, sedangkan unutk mengetahui tingkst kepuasan responden peneliti mengunakan skala likert.

Tabel 1 skala likert

\begin{tabular}{|c|l|}
\hline Bobot & \multicolumn{1}{|c|}{ MAKNA NILAI } \\
\hline 1 & Sangat kurang baik \\
\hline 2 & Kurang baik \\
\hline 3 & Cukup baik \\
\hline 4 & Baik \\
\hline 5 & Sangat baik \\
\hline
\end{tabular}


Tabel 2 Bobot skala likert

\begin{tabular}{|c|l|}
\hline presentasi & \multicolumn{1}{|c|}{ Keterangan } \\
\hline $0 \%-19,99 \%$ & Sangat kurang baik \\
\hline $20 \%-39,99 \%$ & Kurang baik \\
\hline $40 \%-59,99 \%$ & Cukup baik \\
\hline $60 \%-79,99 \%$ & Baik \\
\hline $80 \%-100 \%$ & Sangat baik \\
\hline
\end{tabular}

Adapun hasil ujicoba sebagai berikut.

a. Uji kelompok kecil

Tabel 3 Uji responden kelompok kecil

\begin{tabular}{|c|l|c|c|l|}
\hline No & \multicolumn{1}{|c|}{ Aspek yang dinilai } & Rata2 & presentasi & Keterangan \\
\hline 1 & Aspek pemograman & 4,65 & $93 \%$ & Sangat Baik \\
\hline 2 & Aspek isi & 4,65 & $92 \%$ & Sangat Baik \\
\hline 3 & Aspek Tampilan & 4,54 & $90,4 \%$ & Sangat Baik \\
\hline 4 & Aspek efisiensi & 4,92 & $98,4 \%$ & Sangat Baik \\
\hline Keseluruhan indikator & $\mathbf{4 , 6 9}$ & $\mathbf{9 3 , 4 \%}$ & Sangat Baik \\
\hline
\end{tabular}

Tabel 4 Uji responden kelompok besar

b. Uji Kelompok Besar

\begin{tabular}{|c|l|c|c|l|}
\hline No & \multicolumn{1}{|c|}{ Aspek yang dinilai } & Rata2 & presentasi & Keterangan \\
\hline 1 & Aspek pemograman & 4,47 & $91 \%$ & Sangat Baik \\
\hline 2 & Aspek isi & 4,2 & $87 \%$ & Sangat Baik \\
\hline 3 & Aspek Tampilan & 4,1 & $84,4 \%$ & Sangat Baik \\
\hline 4 & Aspek efisiensi & 4,3 & $88,4 \%$ & Sangat Baik \\
\hline \multicolumn{2}{l|}{ Keseluruhan indikator } & $\mathbf{4 , 2 6}$ & $\mathbf{8 7 , 8 \%}$ & Sangat Baik \\
\hline
\end{tabular}




\section{Kesimpulan dan Saran}

Berdasarkan hasil penelitian yang telah di akukan dapat disimpulkan bahwa :

\section{A. Kesimpulan}

a. Penelitian ini menghasilkan produk berupa sistem jurnal mengajar dosen berbasis website. Tahapan yang dilakukan untuk menghasilkan sebuah sistem jurnal mengajar dosen berbasis website melalui tahap pengumpulan informasi, tahap perencanaan, pentujian blackbox dan ujicoba. sistem jurnal mengajar dosen berbasis website yang di racang juga dilengkapi dengan fitur menu seperti beranda, struktur organisasi, jurnal, rekap dan logout.

b. Hasil wawancara dengan sekretaris Prodi PTI Unimuda Sorong, ahli dan responden secara keseluruhan menunjukkan tanggapan yang baik terhadap penggunaan sistem jurnal mengajar dosen. Dari sisi efisiensi didapatkan dari pengujian kelompok kecil dan kelompok besar yang terdiri dari kelompok kecil berjumblah 5 responden dan kelompok besar 10 responden yang teridiri dari 3 dosen PTI dan 12 dosen Unimuda Sorong yang dipilih secara acak, kemudian sistem jurnal mengajar dosen diopersikan responden diikuti pengisian angket responden yang didalamnya terdapat butiran soal dari berbagai aspek. Hasilnya yang didapat dari kelompok kecildari aspek pemograman dengan nilai rata-rata 4,65 dengan peresentase 95\% kategori sangat baik, aspek isi dengan rata-rata nilai 4,65 dengan peresentase 92\% kategori sangat baik, aspek tampilan dengan nilai rata-rata 4,54 dengan peresentasi 90,4\% kategori sangat baik dan aspek efisiensi dengan nilai rata-rata4,92 dengan peresentase $98,5 \%$ kategori sangat baik sedangkan kelompok besar aspek aspek pemograman dengan nilai ratarata 4,47 dengan peresentase $91 \%$ kategori sangat baik, aspek isi dengan ratarata nilai 4,2 dengan peresentase $87 \%$ kategori sangat baik, aspek tampilan dengan nilai rata-rata 4,1 dengan peresentasi $84,4 \%$ kategori sangat baik dan aspek efisiensi dengan nilai rata-rata 4,3 dan presentase 88,4 kategori sangat baik.

\section{B. Saran}

Adapun saran yang nantinya dapat dikembangkan pada sistem informasi jurnal mengajar dosen berbasis web ini antara lain :

a. Sistem yang dibangun harus mempunyai fitur register unutk mendapatkan akun pribadi

b. Terdapat fitur yang dapat merekap jurnal mengajar dosen permatakuliah maupun perdosen.

\section{Daftar Pustaka.}

Alfaris, H. B. I., Anam, C., \& Masy'an, A. (2016). Implementasi Black Box Testing Pada Sistem Informasi Pendaftaran Santri Berbasis Web Dengan Menggunakan PHP dan MySQL. SAINTEKBU: Jurnal Sains Dan Teknologi, 6(1), 23-38.

Andriani, L., Informasi, S., Pasien, P., Jalan, R., Rumah, D., Dengan, S., ... Repository, U. S. 
U. (2009). Lidya Andriani: Sistem Informasi Pendaftaran Pasien Rawat Jalan Di Rumah Sakit Dengan Menggunakan Program Komputer, 2009. USU Repository (C) 2009.

Astuti, P. (2018). Penggunaan Metode Black Box Testing (Boundary Value Analysis) Pada Sistem Akademik (Sma/Smk). Faktor Exacta, 11(2), 186.

Bekasi, N. (2019). Pembuatan aplikasi sistem ujian online pada smk garuda nusantara bekasi. (January).

Ilmiah, A. (2016). Otomatisasi Sistem Pendaftaran dan Penjadwalan Ujian Skripsi Fakultas Teknologi Informasi Universitas Kristen Satya Wacana. (672012053).

Junaidi, A., \& Sumirat, C. (2018). Aplikasi Persediaan Barang PT . CAD Solusindo. 07, 2837.

Linda, D. (2016). Merancang e-katalog Berbasis Website Sebagai Media Informasi pada Badan Perpustakaan Arsip dan Dokumentasi Daerah (BPAD) Lampung.

Palit, R. V, Rindengan, Y. D. Y., \& Lumenta, A. S. M. (2015). Rancangan Sistem Informasi Keuangan Gereja Berbasis Web Di Jemaat GMIM Bukit Moria Malalayang. 4(7), 1-7.

Permendikbud. (2016). Journal of Economics and Finance, 3(1), 56.

Santoso, A. H. (2017). Sistem Informasi Perpustakaan Sekolah Berbasis Visual Basic Di Smk Muhammadiyah 2 Moyudan.

Sholihin, M., \& Mujilahwati, S. (2017). Sistem Penerimaan Peserta Didik Baru Berbasis Web ( Online ) Di SMK Muhammadiyah 7 Kedungpring Lamongan. 6(1), 557-560.

Web Studi Kasus Pondok Pesantren Al-Habi Sholeh Kabupaten Kubu Raya, B., \& Barat Yoki Firmansyah, K. (2018). Penerapan Metode SDLC Waterfall Dalam Pembuatan Sistem Informasi Akademik. Jurnal Teknologi \& Manajemen Informatika, 4(1).

Yulianti, L., Aspriono, H., Tetap, D., Ilmu, F., Universitas, K., \& Bengkulu, D. (2011). Website Unit Pelaksana Teknis Dinas ( Uptd ) Puskesmas Jembatan Kecil Kota Bengkulu Menggunakan Adobe Dreamweaver Cs3 Science and technology evolve in line with the progress of activities undertaken to support humans. The computer is one of the results $0.7(2)$. 